\title{
WNT7A wt Allele
}

National Cancer Institute

\section{Source}

National Cancer Institute. WNT7A wt Allele. NCI Thesaurus. Code C53008.

Human WNT 7A wild-type allele is located in the vicinity of 3p25 and is approximately 14 $\mathrm{kb}$ in length. This allele, which encodes protein wnt- $7 \mathrm{a}$, is involved in embryonic cell fate determination. 